\title{
Tax Disincentive as a Prevention for Environmental Pollution
}

\author{
Dewi Kania Sugiharti ${ }^{1}$ and Zainal Muttaqin ${ }^{2}$
}

\begin{abstract}
The tax function has associated with the nation goal, that are to accommodate the financial interests of government and at the same time capable to provide space for environmental protection and do not inhibit creativity of the community to try to create a decent life and prosperity. State has authority to implementing tax policies. The tax functions in Indonesia have not yet harmonious and balanced, because the government lead more on the budgetary function and the state budget allocations are not based on state revenue. The ideal concept of tax law for Indonesia is in accordance with the Indonesian legal idea. The establishment and enforcement of tax laws must always manifest that values, which is given the mandate by and accountable to God Almighty, so that in its application felt to be fair, humane and civilized, capable of creating national unity and realize the welfare of all Indonesian people. Setting the disincentive of taxes in the national legal tax system of Indonesia, connected with the application of environmental protection, should be integrated in the tax law, while the settings are currently scattered in various laws and regulations with substantially different purposes. National tax law is expected to achieve certainty, fairness and benefits for all Indonesian people.
\end{abstract}

Keywords: Indonesian, tax, law

\section{Introduction}

There is an issue that state that environmental damage is getting crucial along with the industrial construction by the reason for improving the fulfillment of life and the welfare of mankind.

Whether people realize about that phenomenon or not, the development make a big impact to the environment. The environment referred can be defined as objects, nature, living creatures, and the place where they live. To respond to these impacts, the Indonesian government has proposed the development with the concept of environmental safety since 1987. At the same time, the ministry of environment was formed and it has a main responsibility to coordinate environmental policy in dealing with environmental problems. As a written guide, there is a legal instrument in the form of law no 23 year 1997 which are then converted to law no. 32 year 2009 about the protection and environmental management.

Various instruments for the prevention and law enforcement in order to protect the environment has been provided both preventive and repressive, including licensing, the report on the environmental impact assessment review or Analisis Dampak Lingkungan (AMDAL) in Bahasa, administrative sanctions, compensation, and even criminal sanctions. However, in its implementations, these instruments is not quite effective as the environmental damage still often occurs, such as pollution due to industrial waste, the burning of forests, and forth.

In addition, law no. 32 year 2009 providing another instrument which is in the form of economic instruments that is set in article 42 clause 2 . Including in an instrument is the application of incentive and disincentive tax.

In a system of taxation in Indonesia, the application of incentives given to taxpayers who do business activities that got priority from the government as regulated in the law no. 25 years of 2007 about capital investment. In relation to environmental safety, the application of incentives and a disincentive tax has not yet been done. Hence, this research aims to find the concept of the application of incentive and disincentive taxs for those who have a role in environmental pollution as mandated by law no. 32 years of 2009 .

In terms of its function, can be distinguished the function of a tax, which are budgeter and regulerend. The budgeter function is a function which is in a public sector, tax used as an instrument for a way to put the money into the state treasury which in turn will be used to finance the state's expenses. Meanwhile, regulerend function means a tax used as a tool to achieve certain objectives which are outside the field of financial and its usually seen in the private sector. Hence, from the function of the tax, it is clear that the government has an important role in determining the direction of policy in the field of taxation. It was because the national development can be done by either the government for public sector or by private sector for private sector.

\section{Objective}

To answer the question on how a system of taxation in Indonesia can apply incentives and disincentive tax to taxpayers who make environmental pollution or damage.

\section{Analysis}

\section{A. Tax Incentive}

The efforts to protect the environment from damage can be done either through efforts to prevent (preventive) as well as with the restoration (represive). Licensing is an important means to prevent the occurrence of the destruction of the environment by human beings. A prior business activity that may give negative impact to the environment, there are strict rules that regulate about the environmental impact assessment that written on AMDAL. A permit to the do a business activity given by the government through the letter of permission and should also give by the community, particularly the one who will be around locations that will be affected directly by these activities. Despite this, licensing is not only the preventive efforts, because prevention efforts can be done through regulation and the application of incentives and a disincentive tax. There is a strong relationship between AMDAL, the licensing, and incentives along with a disincentive tax. Through AMDAL, an activity that affects the environment can be anticipated and the government should not give permission for the activity 
which brings a potential of environmental destruction. It is clear that from the beginning the government should be able to determine what kind of activities that will be given incentives or a disincentive.

In general, tax incentives are defined as the facility in the areas of taxation to taxpayers that has certain qualification to do business activities in accordance with the prevailing regulation and also have an advantage compared with facilities that given to taxpayers in general.

Tax incentives are commonly granted in the form of tax exemption, tax holiday, deduction from the taxable base, reduction in the rate of taxes, tax deferment, and others.

The policy of tax incentives in Indonesia never associated with environmental problems. The provision of tax incentives that is arranged in capital investment law are based on considerations or the criteria of a large number of investors who are able to absorb much labor, certain sectors which are nominated as a priority, and the place or region of the business activities. These tax incentives granted in order to equalize the development outside Java Madura so urbanization inhabitant to Java as a region that already crowded inhabitant is not occurring.

In the law of taxations, environmental aspects not yet included in a system of taxation comprehensively. Government concern for the environment in new taxation systems is newly found in article 7 paragraph 1 of a number 5 law of income tax. The article determines that for taxpayers who do the processing of waste that produce from of their business activities, then the costs for processing the waste should be reduced from income or the gross profit. Thus, the profit of taxpayers who subject to income tax will be smaller.

The restrictions about how much expense for waste processing that can be deducted from income or the gross profit it was not clear. Based on that statement, the cost of waste processing is limited to taxpayers who are producing waste in their business activities. Pollution for the environmental damage that is not occurring or caused by the waste, cannot use of the cost that already mention earlier as a tax incentive.

Therefore, in order to give impetus to preserve the environment, tax incentive should not only be given to taxpayers who generate waste from their business operation.

\section{B. Tax Disincentive}

Explanation of the article 42 clause 2 c law no. 32 year of 2009 gives the definition of disincentives as the imposition of a load or threat in monetary and/or non monetary to everyone in order to reduce the activities that give negative impacts on natural resources and also to the quality of environmental functions.

From the statement above, a disincentive is the opposite of the incentive, because it is a judgement that are repressed. Once the tax disincentive applied to taxpayers who contribute to environmental pollution or damage, they can be considered to pay a tax with higher rate than the general one. Taxation with a higher rate is a punishment as a result of the taxpayers violated the Environmental Law. Nevertheless, this does not mean taxpayers as pollution players can be free from other sanctions. Thus, the imposition of these prices are must be regulated in the law in accordance with the principle of taxation in.

The implementation of incentive and disincentive tax is not necessarily able to save the environment. However, it is necessary for the government policy to provide a legal rule on this problem. Relating to the effectiveness of the rewards and punishments, there was a research by James Andreoni and William Harbaugh, their research is not about the tax aspects and environment, but with regard to the application of the strategy of carrot and stick against employee performance.

According to Siti Sundari Rangkuti ${ }^{1}$, in the field of environmental policy, it is mentioned about the economics instruments that their benefits are relative to the management of the environment. Concerning the environmental policy from Organisation for Economic Co-operation and Development (OECD), it is knows the following terms:

a. direct control;

b. taxes;

c. payments;

d. subsidies;

e. various incentives (tax benefits, accelerated amortization, credit facilities);

$f$. the auction of pollution rights;

g. charges"

The relationship between the tax problems with the aspects of environment can be thought of two theories, as suggested by William R. Scott ${ }^{2}$ that is : the public interest theory dan the interest group theory. According to William $\mathrm{R}$. Scott ${ }^{2}$, based on the public interest theory, regulation is the result of a public demand for correction of market failures and regulator is assumed to have the best interests of society at heart to maximize social welfare, but based on the interest group theory, the formation of the rule was influenced different interests from community groups, for example the environmentalist would be concern about the industry's social responsibility.

In addition to preventive efforts, the protection also can be done by means of repressive, although the manner of repressive not be able to restore the function of environment that is already damaged. Repressive way done by means of law enforcement agents against pollution. For example, in the case of burning forest. The punishment against the perpetrators of forest, will give a deterrent effect to the suspect, but could not restore the function of the forest have been damaged. In addition, burning forest might cause air pollution that endangers to the health community, adverse economic (e.g. smoke cause disturbances in the flight of an airplane and the aggrieved side is not just an airline, but passengers also suffered losses).

A fact indicating, offender the burning forest has been charged with criminal punishment either by virtue of The

\footnotetext{
${ }^{1}$ Siti Sundari Rangkuti, Hukum Lingkungan dan Kebijaksanaan Lingkungan Nasional, edisi ketiga, Airlangga University Press, Surabaya, 2005, pp. 260

${ }^{2}$ Scott, R.William, Financial Accounting Theory, Prentice-Hall, Inc, Canada, 1998, pp. 357
} 
Act Number 32 year 2009 about Management And The Environmental Protection and The Act Number 18 year 2013 about Prevention and Eradication of Deforestation. In this case, although The Act of Management And The Environment Protection arrange a tax disincentive for the polluter, but the provisions were not applied in practice. The issue caused the tax law is not connecting it with the behavior of defiling or not defiled environment, for example The Act Number 36 year 2008 about Income Tax, regulate tax rates only based on a layer of taxable income or the amount of company profits.

\section{Conclusion}

A disincentive tax in the sub-system taxation laws of Indonesian, within the framework of protection of the environment, has not been integrated, because the arrangement to be contained in the act of the management and protection of the living environment that substantially have a purpose different from the tax laws. In a theoretical manner, when going on a regulation that is different about a thing between rules of equal rank, can be used the principle of "lex specialis derogat lex generale". Nevertheless, in the implementation of this regulation can give rise to difficulties for those responsible for implementing regulations, for example tax officers will focus on tax regulations, while environment officers will focus on the regulation on the environment. That this will cause uncertainty of law and injustice.

\section{Acknowledgment}

Research on Tax Disincentive as a Prevention for Environmental Pollution was done using a method of juridical, with the secondary sources of data consisting of tax legislation and regulations relating to the environment which prevails in Indonesia, as well as some literature that deals with the object of research. A source of research funds coming from the Faculty of Law, Padjadjaran University.

\section{References}

[1] Rochmat Soemitro, Pajak dan Pembangunan, Eresco, Bandung, 1988, pp.9

[2] Andreoni,,James, "The Carrot or the Stick:Rewards, Punishments and Cooperation", University of Pittsburgh, 2002, pp. 20

[3] Siti Sundari Rangkuti, Hukum Lingkungan dan Kebijaksanaan Lingkungan Nasional, edisi ketiga, Airlangga University Press, Surabaya, 2005, pp. 260

[4] Scott, R.William, Financial Accounting Theory, Prentice-Hall, Inc, Canada, 1998, pp. 357

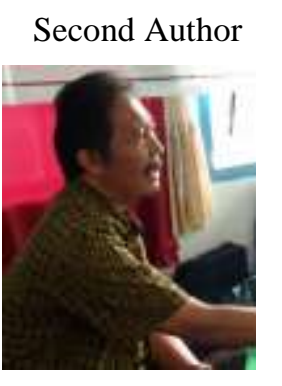

Dr. Zainal Muttaqin, S.H.MH is an assosiate professor of taxation law at the Faculty of Law, Padjadjaran University, Bandung, Indonesia. Teaches taxation law and administrative law.

About Authors:

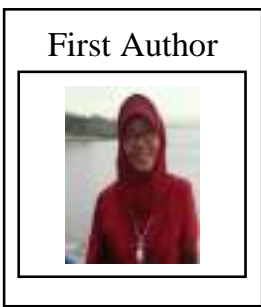

Dr. Dewi Kania Sugiharti, S.H.MH. is an assosiate professor of taxation law at the Faculty of Law, Padjadjaran University, Bandung, Indonesia. Teaches: taxation law, public finance law and administrative law. A guess lecturer at the Universitas Islam Riau (UIR), Pekanbaru Riau, Sumatera, Indonesia. 